\title{
Enabling Smallholder Prosperity through Commercialization and Diversification
}

\subsection{INTRODUCTION}

India will be the most populous country in the world with a population of 1.65 billion citizens by the year 2050 . Keeping in mind the need to achieve zero hunger, the two central concerns for food security is how to increase productivity and how to diversify food production. Growth in productivity is needed to eradicate all forms of hunger in the existing population and safeguard the future generation from it, and diversification of production is essential to meet the demand for higher value crops resulting from income growth and ensure more availability of micronutrients. However, the way forward in achieving higher productivity and diversity of foods needs to reduce agriculture's effect on the environment. Adapting agricultural production growth with current and ongoing climate change consequences such as temperature and precipitation change and replenishing natural resources required for agriculture that is lost or on the verge of loss, forms the core supply challenge for global and Indian agriculture.

In India, where a majority of agricultural producers are small and marginal in size, commercialization of farms by which smallholders produce for the market is essential to improve incomes and better access to diversified and nutritious food. The rising demand for diversified agricultural products has brought about opportunities and challenges for India's agricultural sector. The opportunities come from increasing demand for diversified and higher value crops that can improve agricultural incomes

(C) The Author(s) 2019

P. Pingali et al., Transforming Food Systems for a Rising India, Palgrave Studies in Agricultural Economics and Food Policy, https://doi.org/10.1007/978-3-030-14409-8_7 
(Pingali, Khwaja, \& Madelon, 2005) and improved access to a varied food basket at the household level. The major challenge, however, is the set of problems associated with the supply side conditions such as poor access to credit and other input markets that have hindered commercialization and made income opportunities inaccessible to many producers. In this chapter, we assess the major institutional features of smallholder production challenges and potential solutions to rectify them. Specifically, we look at (a) the benefits and limits of the Green Revolution to determine the current supply and nutritional challenges of the Indian food system, (b) the production constraints smallholder agricultural systems currently face in the context of commercialization and meeting food security and economic growth challenges and $(c)$ the general direction interventions need to take in order to meet the goals of sustained productivity growth and diversification.

\subsection{Farm Size, Yields and Regional Disparities- Benefits and Limits of the Green Revolution}

A majority of the world's agricultural production takes place on small and marginal farms, and despite recurring predictions that small farms will soon disappear, they have persisted and in many cases have increased in number (Hazell, Poulton, Wiggins, \& Dorward, 2010; Hazell, 2018). In India, the average size of landholdings decreased from 1.33 hectares in 2000-01 to 1.15 hectares in 2010-11. Considering these trends, assessing small farm viability becomes critical. Understanding the relationship between land size and productivity is essential to identify the potentials and challenges for small farms. The relationship between size of landholdings and productivity has been debated in the field of rural development and economics for a long time. Since the 1960s, economists have argued that crop productivity per unit of land declined with an increase in farm size (Bardhan, 1973; Mazumdar, 1965; A. Sen, 1962). Referred to as the "small farm paradigm", it was argued that there is an inverse relationship between farm size and productivity. These studies conclude that small farms have an advantage over large farms in per capita productivity due to higher labor utilization (e.g., using family labor) and higher input utilization (e.g., using intensive farming practices). This inverse relationship was a result of imperfect land and labor markets (Bardhan, 1973; A. Sen, 1966). Imperfections in the labor market meant that surplus labor at the household level was available, as off-farm opportunity costs (off-farm wages minus search and 
travel costs) were higher than on-farm wages, and low-cost labor allowed for substituting lumpy inputs such as capital-intensive equipment (Binswanger \& Rosenzweig, 1986; Eastwood, Lipton, \& Newell, 2010; Poulton, Dorward, \& Kydd, 2010). Imperfect land markets meant that land lease options to access more land for farming was limited (Eswaran \& Kotwal, 1986; Hazell et al., 2010) and producers had to utilize their existing resource endowment effectively.

In many Asian countries (where land was scarce and labor abundant), the "small farm paradigm" did hold and was considered a socially optimal outcome (Hazell et al., 2010; Poulton et al., 2010). Johnson and Ruttan (1994) clarify that the size and productivity relations hold when considering scale-neutral inputs associated with the actual production processes such as labor input, monitoring and local knowledge. For these inputs, in the pressure of high monitoring costs (to large farms), small farms are not at a disadvantage and in many cases may have an advantage. However, with factors including access to markets, credit and extension services, technical knowledge and technology, along with lumpy inputs such as management and asset-specific machinery that have high fixed costs and are not scaleneutral, small farms are at a disadvantage (Poulton et al., 2010). Some studies have also shown that the inverse relationship between small size and high productivity disappears when soil quality (Benjamin, 1995; S. S. Bhalla \& Roy, 1988), capital market imperfections (Feder, 1985) and unobserved heterogeneities such as climatic variations and quality of management are considered (Eastwood et al., 2010). In countries like India, where wages are on the rise, there has also been a lowering of off-farm opportunity costs, eroding the labor advantage of small farms (Binswanger \& Singh, 2017). In this section, we look at agricultural development in India in the context of smallholder production to assess the nature of growth and regional disparity trends in the context of the Green Revolution.

\subsubsection{Green Revolution Technologies and Regional and Crop Disparities}

The Green Revolution (GR) was a landmark achievement in technological and institutional innovation that brought about the exponential growth in yields of cereals in many developing countries and saw improved food availability (mainly wheat and rice), a rise in per capita incomes and poverty reduction. This was extraordinary because productivity growth took place in line with population growth, which more than doubled, and when land 
scarcity and land values were rising (Pingali, 2012). Central to the GR strategy was the use of high-yielding variety (HYV) technology in staples such as wheat, rice and maize coupled with appropriate institutional mechanisms to enable widespread adoption across many developing countries (ibid). In countries like India, GR was effectively implemented on small farms because these technologies were (a) scale-neutral and they could be divided and distributed at no extra cost unlike other technologies such as tractors and irrigation (Birner \& Resnick, 2010; G. Feder, Just, \& Zilberman, 1985; Hazell et al., 2010; Mosley, 2002); and (b) it was an international public good that had adequate input support in the form of state-subsidized fertilizers and pesticides and extension services (Pingali, 2012), allowing for the adoption of these technologies by smallholders in many parts of India. The positive impacts of the GR were that it led to significant increases in the yields of wheat and rice that led to lowering of food prices and increased availability, improving food security, and the resulting income growth led to a reduction of poverty in many parts of India (ibid).

Although GR technologies were scale-neutral allowing for adoption on small farms, they were not resource-neutral (Bernstein, 2010) and this meant adoption was influenced by the smallholder's access to resources such as irrigation, markets and credit. Also, as food security was traditionally defined as calorific security, food policy was excessively focused on the promotion of staple grains such as wheat and rice to make available sufficient amount of calories to the population (Pingali, 2015). Relative to staple grains, other crops such as pulses and coarse cereals received limited focus concerning R\&D resulting in limited seed technology development and market support such as direct procurement and support price. Therefore, the regional and crop disparity regarding benefits became stark in the years following the GR, resulting in high interregional inequalities in agricultural development. Much of the eastern region (Bihar, Eastern UP, West Bengal, Odisha and Madhya Pradesh) did not see a change in area under production (Figs. 7.1 and 7.2).

As access to irrigation was vital in determining the regions where GR technologies were implemented, Punjab and Haryana and to a less extent the Indo-Gangetic plains saw an increase in area under production of wheat and rice. Also, in Punjab, the wheat yields are 2 to 2.4 times higher than of other states, and rice yields are 1.5 to 2 times that of states such as Odisha, Maharashtra, Madhya Pradesh and Bihar. During this period, we also see a change in cropping patterns. As the economic benefits of 

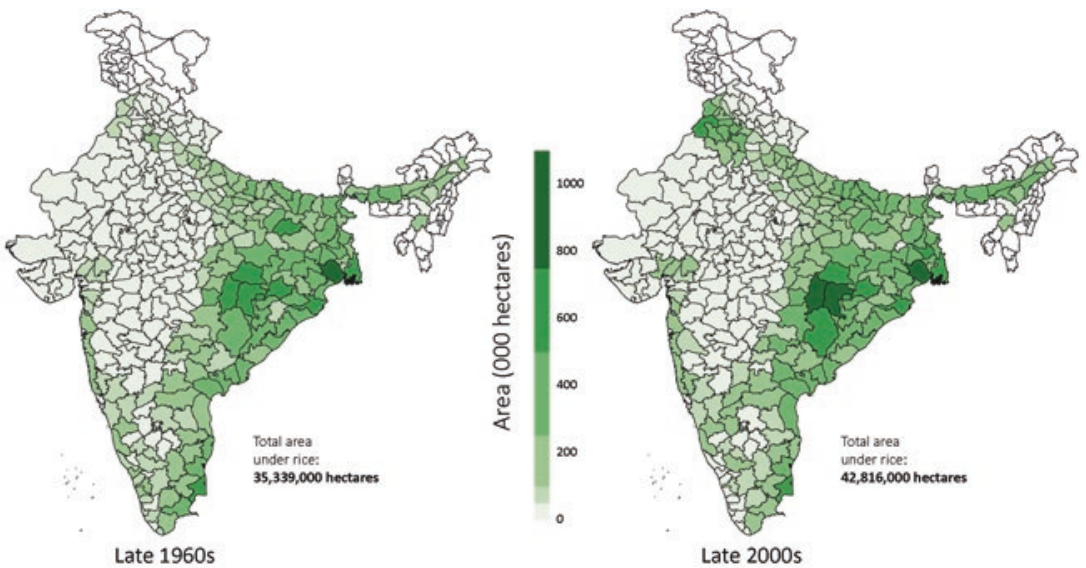

Fig. 7.1 Change in area under production ('000 hectares) of rice between 1960s and 2000s. Source: Ministry of Agriculture and Farmers Welfare, Government of India; based on authors calculation
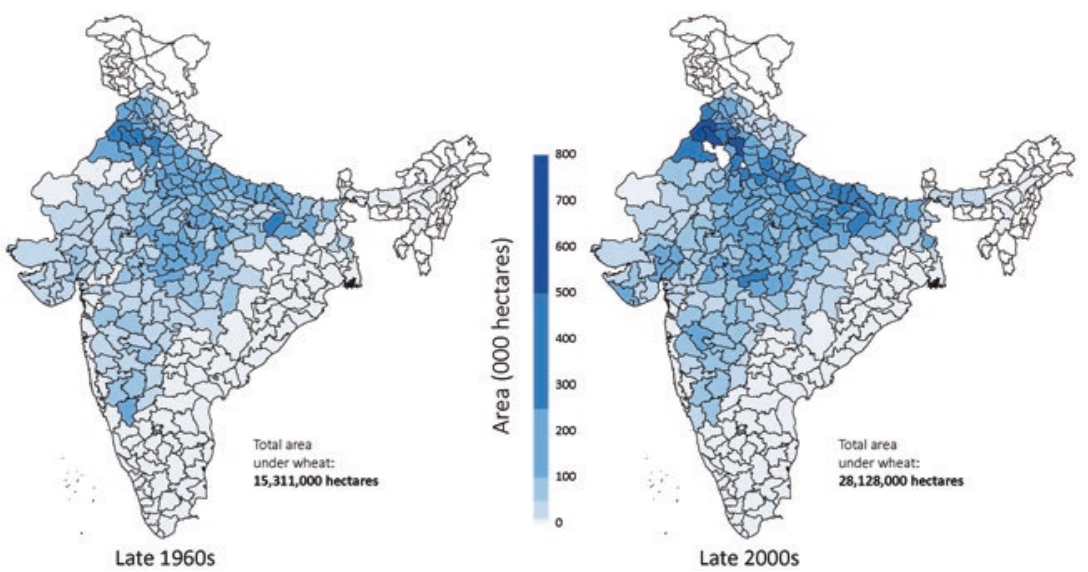

Fig. 7.2 Change in area under production ('000 hectares) of wheat between 1960s and 2000s. Source: Ministry of Agriculture and Farmers Welfare, Government of India; based on authors calculations 


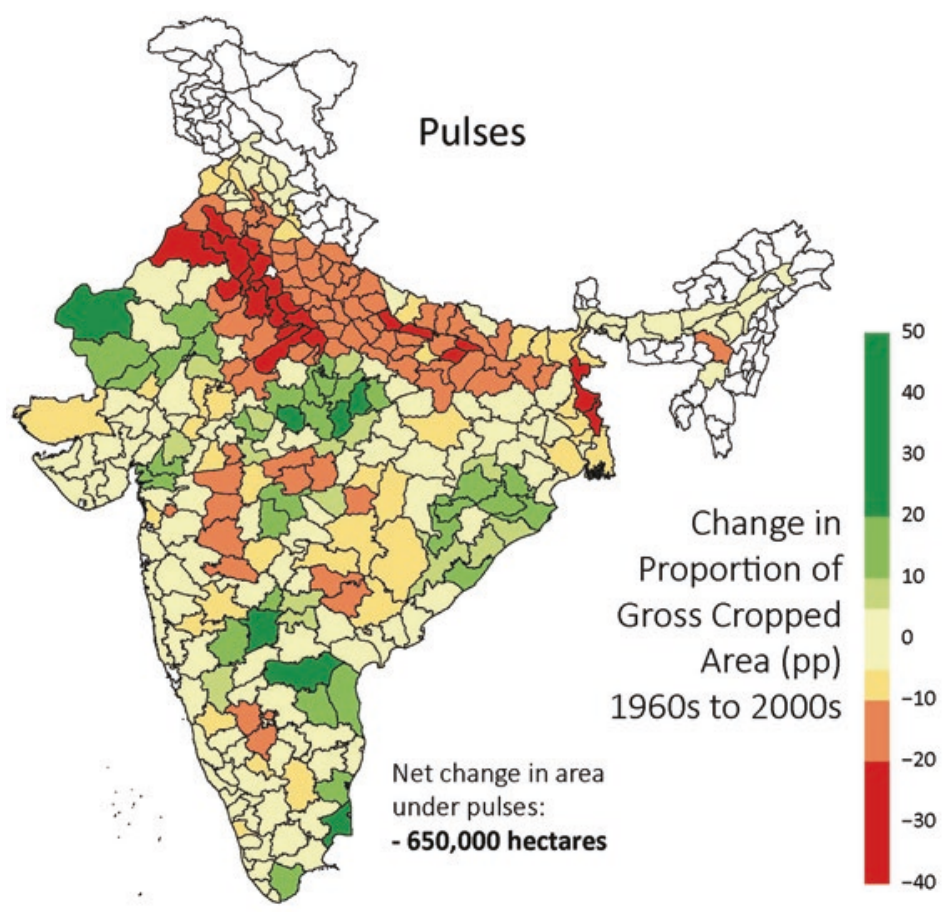

Fig. 7.3 Change in area under production ('000 hectares) of pulses between 1960s and 2000s. Source: Tata-Cornell Institute

increased yields were substantial, it led to the emergence of intensive cropping of wheat and rice in irrigated tracts of India. Figure 7.3 shows the change in the proportion of gross cropped area under pulses in various parts of India. In the irrigated regions that witnessed intense cultivation of wheat and rice, there was a $30-40 \%$ drop in area under pulses cultivation, as pulses were substituted for rice cultivation in GR adopted regions and pulses cultivation shifted to the central parts of India (Abraham \& Pingali, 2019; Pingali, 2012).

Figure 7.4 shows the per capita availability of various food grains in India from 1951 to 2015 . In the case of cereals, we see availability increased from 65.7 to 168 grams per capita per day in wheat and from 158.9 to 186 grams per capita per day in rice to increase production in line with population growth. In the case of pulses where comparable technological 


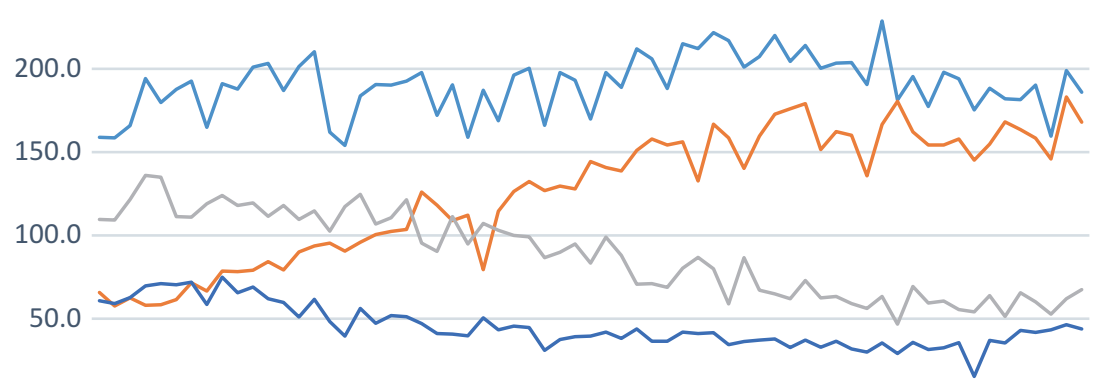

0.0

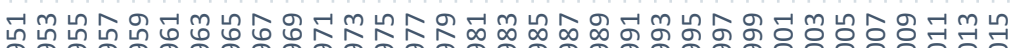

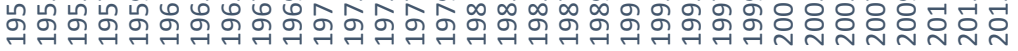
Rice Wheat Coarse grains - Pulses

Fig. 7.4 Per capita availability of cereals, coarse grains and pulses in India (1951-2015). Source: Ministry of Agriculture and Farmers Welfare, Government of India

and institutional interventions were missing, production and area under cultivation stagnated, leading to a decline in per capita availability from 60 grams per day per person in 1951 to 43 grams in 2015. Yields witnessed only a marginal increase $(251 \mathrm{~kg} /$ hectare $)$ in the last 65 years. In the case of coarse grains (such as sorghum, pearl millets, finger millets, barley etc.) per capita availability decreased from 109.6 in 1951 to 67.4 grams per day in 2015 . Despite an increase in yields from $579 \mathrm{~kg}$ per hectare to $1579 \mathrm{~kg}$ per hectare in coarse cereals during the same period, the area under cultivation decreased by about $60 \%$, leading to lower supply.

The advantage of the GR was that it was scale-neutral and could be adopted by small and marginal producers provided they had access to irrigation or were in locations with reduced agro-climatic risk. Institutional support and favorable policy in the form of subsidized inputs and extension services and market support through minimum support prices and direct procurement by the state played a crucial role in enabling and incentivizing adoption. GR was also a watershed in agricultural development that played a critical role in poverty reduction and significantly reducing hunger. The limits of GR were that it was focused on significant staple grains such as wheat and rice and was limited to regions that were not resource constrained. The current challenges for the India food system are to ensure diversification to higher value crops to ensure the availability 
of nutritious foods and ensure income growths through productivity increases, especially in lagging states that did not benefit from the GR. Central to ensuring broad-based growth and development in the agricultural sector is rectifying the institutional and resource constraints of smallholder production. The next section of this chapter discusses the significant production challenges of smallholder agricultural systems in diversification and commercialization.

\subsection{Production Challenges-Small Farm Diversification, Commercialization and Risks}

Income, urbanization and population growth are the main drivers of demand of agricultural produce, and the supply challenge for the agricultural sector in meeting this demand is two-pronged: one, to increase cereal production to keep up with rising population, and two to ensure the availability of diversified food groups that cater to increasing demand. Commercialization of smallholder agriculture is central to meeting this demand. Commercialization is the process by which farms increase their engagement with input and output markets as they move away from integrated or subsistence farming systems to specialized crop and livestock production (Pingali \& Rosegrant, 1995). During the transition, nontraded inputs are substituted for purchased seeds, pesticides and fertilizers that enable production increase and diversification of production and selling in output markets (Carletto, Corral, \& Guelfi, 2017; Pingali \& Rosegrant, 1995; von Braun, 1995). Commercialization is central to the structural transformation process as greater input market orientation increases the demand for industrial goods and technology essential for production, increases household welfare through employment generation and increased labor productivity and enables the transfer of surplus in the form of food, labor and capital from the agrarian sector to the other sectors.

In India, the regional disparities in rates of commercialization have been varied. Regions that benefited from the GR witnessed growth in yields through the use of high-yielding seed technologies, fertilizers and pesticides, while in unirrigated regions where agro-climatic risks were high, production systems remain semi-commercial due to lower surpluses. The ability to smallholder agriculture to transform from subsistence and semi-commercial farming to commercialized farming requires linkages to factor markets to access credit, land, inputs (seeds, fertilizer and pesticides) and technology. In this section, we look at the significant 
challenges to diversification, the disadvantages of smallholders to commercialize due to capital market imperfections and changing characteristics of inputs markets.

\subsubsection{Small Farms and the Costs of Diversification}

Diversification of production at the farm level is critical for food security through increased availability of nutritious food and for improving incomes. However, the ability to diversify is determined by both policy and access to factors of production such as seeds, fertilizer and pesticides, credit and extension services. Food policy in India has traditionally focused on concerns of calorific security, where it aimed to ensure the availability of sufficient calories for its citizens (Varshney, 1998). GR technologies focused mainly on wheat and rice and agricultural policies focused on price support and direct procurement aimed to bring about intensive cereal-based transformations (de Janvry \& Subbarao, 1986; Dorward, Kydd, Morrison, \& Urey, 2004; Freebairn, 1995; Goldman \& Smith, 1995).

In comparison, food grains such as coarse cereals and pulses did not see much technological intervention or market support. The unintended consequence was that it reduced the incentives for the cultivation of micronutrient-rich coarse grains and pulses in favor of wheat and rice affecting the availability of micronutrient-rich foods.

Costs of producing and selling different crops vary depending on their characteristics as commodities or products. Commodities are "Standardized agricultural products that have had little or no processing and often raw materials for further procession" (Schaffner, Schroder \& Earle, 1998, p. 6). Products are commodities that are differentiated based on attributes (organic, processed, branded, variety, perishability) or commodities with value addition (Reardon \& Timmer, 2007). The notable difference between commodities and products is that commodities are fungible (substitutable) raw materials or produce like corn, wheat, rice, crude oil or iron ore, while products are of higher value, perishable and often require specialized value chains.

The cost dynamics for growing commodities and products are fundamentally different and this influences the ability of farms to diversify. Table 7.1 highlights the various features on which commodities and products differ at the farm level. As products such as fruits and vegetables, milk, and so on are highly differentiated, they may require higher labor inputs, monitoring and higher levels of credit access to procure quality 
Table 7.1 Factors influencing costs at the farm level for commodities and products

\begin{tabular}{lll}
\hline Characteristics & Products & Commodities \\
\hline Labor input & $\begin{array}{l}\text { Higher labor inputs to manage } \\
\text { crops at the farm level. Pesticide } \\
\text { and fertilizer application }\end{array}$ & $\begin{array}{l}\text { Relatively low. Labor requirements } \\
\text { during sowing and harvesting are high }\end{array}$ \\
Monitoring & $\begin{array}{l}\text { Higher monitoring is required } \\
\text { to control for quality and grade } \\
\text { during the growing process }\end{array}$ & $\begin{array}{l}\text { Constant monitoring is not required } \\
\text { and this may contribute to lower labor }\end{array}$ \\
& $\begin{array}{l}\text { Higher labor and monitoring } \\
\text { along with the need for quality } \\
\text { inputs raises the need to access } \\
\text { credit } \\
\text { Specific inputs such as seeds, } \\
\text { medicines, fertilizers and }\end{array}$ & $\begin{array}{l}\text { The level of credit needed will be } \\
\text { lower than products }\end{array}$ \\
$\begin{array}{l}\text { pesticides may be needed, raising } \\
\text { the costs of access and } \\
\text { negotiation }\end{array}$ & $\begin{array}{l}\text { Subsidized inputs such as seeds, } \\
\text { fertilizers and pesticides available, } \\
\text { reducting the cost of production and } \\
\text { access costs compared to products }\end{array}$ \\
\hline
\end{tabular}

inputs as grades and standards requirements for marketing products may be more stringent. This raises the costs of production and management at the farm level for products in comparison to commodities.

The capacity of small farms to diversify from commodities to high-value products has production and management costs and risks associated with them. The willingness of farming households to diversify or stay in semicommercial production systems will depend on behavioral characteristics such as levels of risk aversion and the ability to withstand and manage those risks. Therefore, access to infrastructure such as irrigation and inputs such as credit and quality inputs in the forms of seeds, fertilizer and pesticides plays an essential role in the ability of smallholders to diversify. Credit availability, changing labor costs and costs of inputs are determining factors not just for diversification but also for agricultural production growth in general.

\subsubsection{Challenges in Accessing Factor Markets and Improving Supply-Credit, Labor and Input Costs}

The ability of small farms to access credit, labor and inputs such as quality seeds, fertilizers and pesticides determines their capacity to commercialize and improve household level incomes. Access to these factors of production 
is influenced fundamentally by credit availability. Capital market imperfections limit access to credit for farms with low land endowments because they have limited value as collateral (Besley, 1995a, 1995b; Bhaduri, 1977; J. Ghosh, 2013; P. Ghosh, Mookherjee, \& Ray, 2001). As the scope for internally financing agricultural production is limited due to slow turnover of capital for small farms, the need for credit is essential. To assess the potential for smallholder production to commercialize and diversify, we look at the challenges in accessing credit and input markets and the changing dynamics of labor markets.

\subsubsection{Access to Institutional Credit}

The impact increased access to institutional credit has on agricultural productivity in India is well established. Binswanger and Khandker (1992) show that credit access has a positive effect on agricultural output and that it increased the use of fertilizer and investment in livestock and machinery at the farm level. Bhalla and Singh (2010) using a district level analysis show that institutional credit has a positive effect on mechanization and non-labor inputs, and in regions that are technologically backward, the elasticity is much higher. Access to institutional credit (from financial institutions such as banks) is conditioned on the size of landholding and access to irrigation. Financial institutions often do not have enough local knowledge about borrowers regarding their risk profiles, and this makes collateral (irrigated land) an essential criterion for borrowings (Bardhan, 1996). The high cost of acquiring information disqualifies marginal farmers, tenant farmers and households without proper title deeds to the land from accessing credit.

Poor access to banks makes non-institutional sources such as moneylenders and input dealers an important option for credit, affecting profit and growth in the agricultural sector. According to the Situation of Agricultural Households Survey (2014) carried out by the National Sample Survey (NSS), $52 \%$ of all agricultural households in India are indebted. The data also revealed the relationship between the size of landholdings and access to formal credit. Figure 7.5 shows the indebtedness in the agricultural sector with the landholding size of agricultural households. The borrowings of households possessing less than two hectares of land (marginal landholders) are higher from informal sources, and the percentage of borrowing from formal sources goes up with an increase in land size.

Since the early 2000s, there has been a significant drive to improve credit access for agricultural producers. Figure 7.6 shows that between 

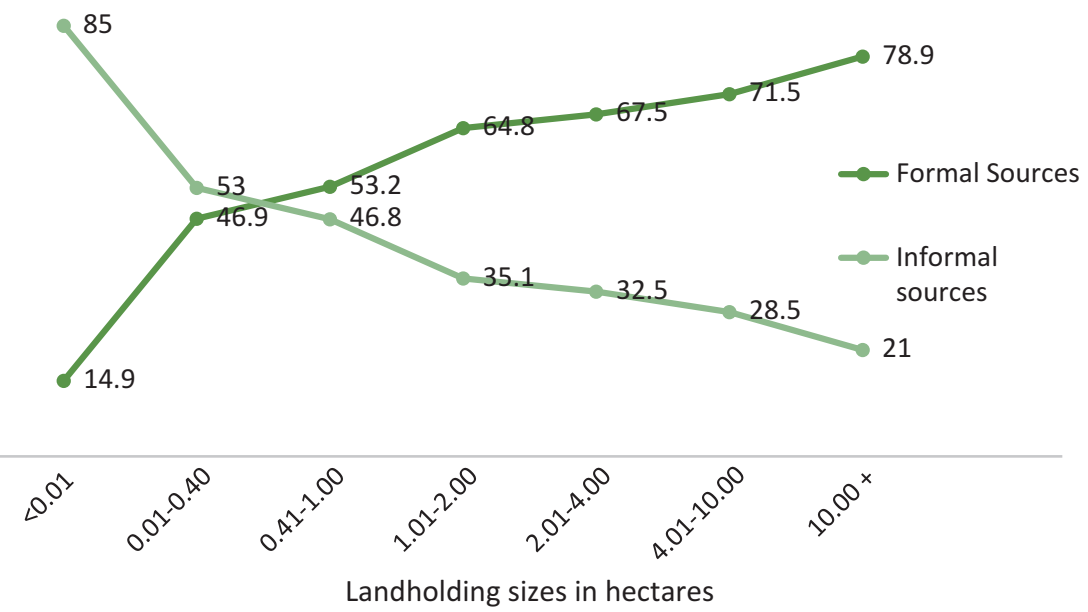

Fig. 7.5 Percentage of indebtedness of different landholding sizes from different sources of credit (2014). Source: Situation of Agricultural Households Survey, NSSO, 2014

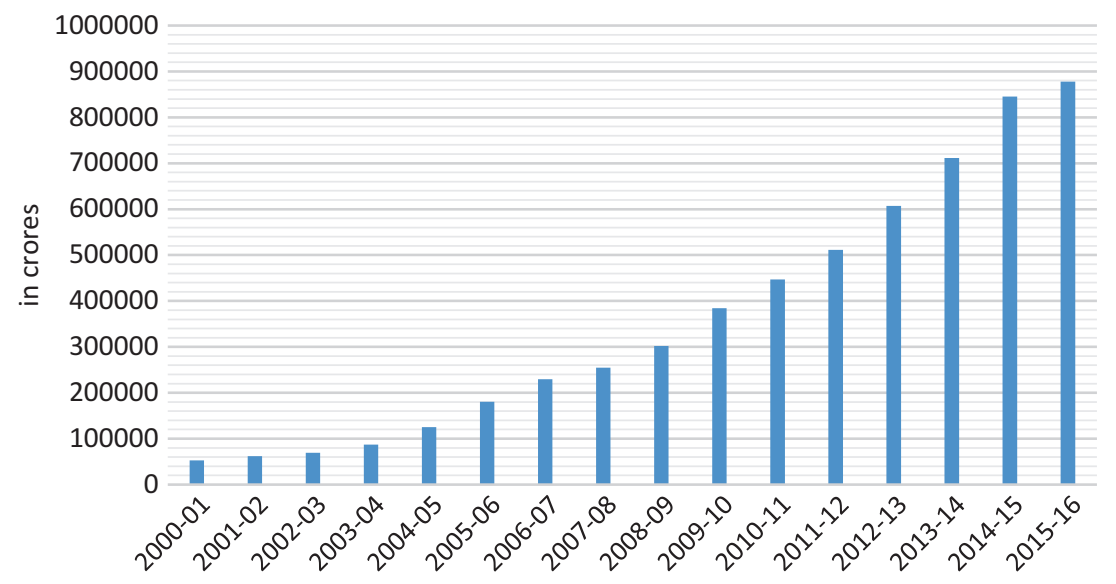

Fig. 7.6 Institutional credit to the agricultural sector (2000-01 to 2015-16). Source: Ministry of Agriculture and Farmers Welfare, Government of India 
2000-01 and 2015-16 overall agricultural credit grew 16 times from 52,827 crores to 877,527 at the compounded annual growth rate (CAGR) of $20.6 \%$. However, there are notable regional variations with the southern regions accessing 39\% of the total agricultural loans. The lagging states in the central and eastern zones receive a lower proportion of $7 \%$ and $12 \%$, respectively (Table 7.2). Schemes such as the Kisan Credit Card (KCC)

Table 7.2 Percentage share of agricultural loan (accounts and amounts) and KCC in 2016 in various states/regions

\begin{tabular}{|c|c|c|c|c|}
\hline \multirow[t]{2}{*}{ Selected states/regions } & \multicolumn{2}{|c|}{ Agricultural loans } & \multicolumn{2}{|c|}{ Kisan Credit Cards } \\
\hline & $\begin{array}{l}\text { Percentage of } \\
\text { bank accounts } \\
\text { to total }\end{array}$ & $\begin{array}{l}\text { Percentage of } \\
\text { loan amount } \\
\text { total }\end{array}$ & $\begin{array}{l}\text { Percentage of } \\
\text { KCC issued since } \\
\text { inception }\end{array}$ & $\begin{array}{l}\text { Percentage of } \\
\text { outstanding } \\
\text { amount }\end{array}$ \\
\hline Andhra Pradesh & 6.86 & 9.80 & 9.69 & 5.79 \\
\hline Karnataka & 5.32 & 5.01 & 6.31 & 6.67 \\
\hline Kerala & 9.06 & 12.15 & 3.48 & 2.01 \\
\hline Tamil Nadu & 5.07 & 3.35 & 6.61 & 2.94 \\
\hline Telangana & 7.94 & 8.56 & 6.63 & 4.04 \\
\hline South Zone total & 34.24 & 38.87 & 32.73 & 21.45 \\
\hline Gujarat & 3.22 & 5.15 & 2.90 & 5.68 \\
\hline Maharashtra & 7.99 & 7.25 & 6.93 & 8.63 \\
\hline Rajasthan & 6.58 & 7.81 & 5.58 & 11.14 \\
\hline West Zone total & 17.81 & 20.27 & 15.42 & 25.45 \\
\hline Haryana & 3.21 & 5.75 & 2.42 & 6.45 \\
\hline Himachal Pradesh & 0.28 & 0.59 & 0.51 & 0.79 \\
\hline Punjab & 2.82 & 9.78 & 2.54 & 10.13 \\
\hline Uttarakhand & 0.56 & 0.73 & 1.32 & 1.34 \\
\hline Uttar Pradesh & 10.80 & 4.31 & 19.50 & 14.86 \\
\hline Jammu \& Kashmir & 0.13 & 0.32 & 0.47 & 0.68 \\
\hline North Zone total & 17.80 & 21.48 & 26.77 & 34.25 \\
\hline Chhattisgarh & 7.51 & 6.02 & 0.52 & 1.04 \\
\hline Madhya Pradesh & 2.06 & 0.98 & 6.12 & 8.46 \\
\hline Central Zone total & 9.57 & 7.00 & 6.65 & 9.51 \\
\hline Jharkhand & 3.65 & 4.68 & 1.27 & 0.60 \\
\hline Bihar & 0.40 & 0.42 & 4.54 & 3.08 \\
\hline Orissa & 6.42 & 2.11 & 5.25 & 2.56 \\
\hline West Bengal & 9.87 & 4.51 & 5.42 & 2.01 \\
\hline East Zone total & 20.34 & 11.72 & 16.49 & 8.26 \\
\hline North East states total & 0.24 & 0.67 & 1.95 & 1.09 \\
\hline
\end{tabular}

Source: Department of Agriculture, Cooperation \& Farmers Welfare, Government of India 
were introduced in 1998 to improve timely access to short-term loans and simplify the process of screening. Again, regional variation in credit access through this scheme has been varied. Table 7.2 shows that the south and north zones have about twice as many credit cards issued and renewed compared to the central and east zones. Uttar Pradesh accounts for 19.5\% of all KCC issued. In a study in the Krishnagiri district of Tamil Nadu, data collected from 120 farmers growing paddy, sugarcane and groundnuts showed that net income and cost of production for farmers with access to KCC were higher (Prakash \& Kumar, 2016). The higher cost of production was attributed to the purchase of higher volumes and quality of inputs for production. A study by NABARD (Mani, 2016) with 714 farming households in 6 Indian states showed that farmer with access to KCC saw an average increase in income of 5462 rupees per acre.

In order for these advantages to percolate more widely, there is a need to increase coverage of KCC especially in the east and central regions. The other challenges that have limited access to KCC have been the time taken to sanction them, socioeconomic biases based on caste and landholding size, low credit limit and lack of awareness among farmers that these provisions are available to them (Kumar, Yadav, Jee, Kumar, \& Chauhan, 2011; Mani, 2016; Prakash \& Kumar, 2016). Addressing these will be essential for smallholder commercialization especially in regions of poor agricultural growth.

\subsubsection{Changing Labor Costs-Effects of Farm Level and Non-farm Wages}

Effective labor utilization of small farms using family labor was the main factor that gave small farms the advantage of higher per capita productivity. As non-farm opportunity costs were higher, labor could substitute capital and lumpy inputs at the farm level leading to efficient labor utilization. In the past two decades, India has seen a growth in real farm wages at the rate of $6.8 \%$ per annum and this is expected to rise with further economic growth (Gulati, Jain, \& Satija, 2014). Simultaneously there has been a growth of non-farm wages as well resulting from the growth of other sectors and rural social programs, especially the Mahatma Gandhi National Rural Employment Guarantee Scheme (MGNREGS) (Binswanger-Mkhize, 2013; Gulati et al., 2014), leading to an increase in farm level opportunity costs. Binswanger and Singh (2017) observe that rising non-farm wages have pulled family labor out of farms as off-farm opportunity costs decrease. They also note that non-farm wage increase tends to pull family labor out 
of the agricultural sector and not hired labor, as they may be older with little education. The pull of family labor effectively erodes the advantage of labor utilization and reduces profits, as farm wages of hired labor is high.

Also, because of the migration of productive male labor, an increase in the feminization of agriculture is taking place (Agarwal, 2010; Pattnaik, Lahiri-Dutt, Lockie, \& Pritchard, 2018). Mechanization will play an essential role in improving agricultural productivity, adjusting for rising wages and reduction of drudgery in farming. In the process of structural transformation, different countries have addressed wage increases through mechanization replacing wage labor, farmers exiting agriculture for nonfarm sectors, diversification to higher value crops to increase income, state expenditure in productivity increasing technologies and raising food prices to support farm incomes (Binswanger \& Singh, 2017). However, the major challenge for small farms with credit constraints and lower than optimal size for mechanization, as it is not scale-neutral, remains. Freeing up land lease markets that can enable small farms to lease in the land, capital subsidies to buy equipment in the wake of credit constraints and aggregation of small farms may be a few solutions to enabling this shift.

\subsubsection{Changing Nature of Input Markets and Access Problems}

The change in dependence on input markets by smallholder households as opposed to depending on using inputs sourced at the farm is an integral part of commercialization. Pray and Nagarajan (2014) argue that the transformation of the agricultural input industry went through two stages. Before the Green Revolution, a majority of seeds, manure, draught and labor was sourced at the farm level. GR technologies shifted the orientation of input access to a greater reliance on markets for seeds and inputs such as chemical fertilizers and pesticides. Initially, State-owned Enterprises (SoEs) played an integral role in the production of inputs. In the late 1980s onward with the liberalization of the Indian economy and postWTO agreements, private firms have emerged to be significant players in agricultural inputs. The opening up of the economy marked the second stage of the input industry transformation. Table 7.3 shows the changing share in private sector involvement in agricultural inputs. Besides fertilizer production, the private sector dominates the sales of other inputs, namely, seeds and pesticides. Concerning farm implements and machinery such as tractors, the private sector has always been the dominant player.

The current challenges of the Indian food system deviate from what GR technologies were designed to and capable of addressing. Concerning issues 
Table 7.3 Changing share of private and public sectors in agricultural inputs (1991-2009)

\begin{tabular}{lccccc}
\hline \multirow{2}{*}{ Industry } & \multicolumn{2}{c}{1991} & & \multicolumn{2}{c}{2009} \\
\cline { 2 - 3 } \cline { 5 - 6 } \cline { 5 - 6 } & Public sector & Private sector & & Public sector & Private sector \\
\hline Share of seeds sale & 35 & 65 & & 20 & 80 \\
Share of pesticides sale & 8 & 92 & & $<1$ & $>99$ \\
Share of tractor sales & 16 & 84 & & 1 & 99 \\
Share of fertilizer sales & 60 & 40 & & 50 & 50 \\
\hline
\end{tabular}

Source: Pray and Nagarajan (2014)

of diversification and resilience and the inputs that are needed to achieve them, the private sector has emerged as the front-runner. Private sector innovations in the past decade have focused on high-value crops such as fruits and vegetables and also coarse grains such as pearl millets and sorghum (Ferroni \& Zhou, 2017). Multinational companies (MNCs) account for $44 \%$ of the seed industry R\&D and have been responsible for a majority of biotechnologybased research, especially genetic modification (Pray \& Nagarajan, 2014). An important aspect relevant in the context of these changes in the input market is the ability of smallholders to access new seed technologies.

Access to capital is essential to increase access to quality inputs. Smallholders have low access to institutional credit and this influences their ability to increase production and diversify through the access to quality inputs and technology. Regions with irrigation and lower climatic risk were able to implement scale-neutral technologies enabling productivity growth during the Green Revolution. The current challenge is to improve agricultural productivity in marginal lands and regions that did not benefit from the Green Revolution. The newer production and seed technologies essential to achieve this requires credit and context-specific information and mechanization. Addressing the issue of scale and access to capital, therefore, remains the two main challenges for smallholder productivity growth in agriculture.

\subsection{The Way Forward: Institutional InTERVEntions to Address Production Challenges and Reducing Regional Disparity}

The ability of smallholder production to adapt to changing demand and the opportunities for growth depend on increasing marketable surplus and diversifying. As production challenges vary according to regions, addressing 
regional disparities is needed to reduce yield gaps and improve livelihoods in poorer states that did not benefit from the Green Revolution. In this section, we first look at the scope of institutional interventions such as aggregation models and land reforms in addressing the issue of scale. Second, we assess the potential of bringing the Green Revolution to the eastern states of India. These measures we argue are critical to address issues related to economies of scale disadvantages to small farms and unequal economic and agricultural development.

\subsubsection{Institutional Interventions in Smallholder Agriculture- Aggregation Models-Revisiting Land Tenure Systems}

In smallholder agricultural systems, the cost of accessing inputs, information and $\mathrm{R} \& \mathrm{D}$ is a challenge for resource-poor small farms. Institutional interventions that can offset disadvantages of small farms and enable effective implementation and uptake of policy targeted at improving production become important. Aggregation models such as producer organizations and cooperatives, where smallholders organize themselves in groups to jointly access resources and market their produce, have shown to reduce transaction cost and form market linkages (Barrett et al., 2012; Bellemare, 2012; Boselie, Henson, \& Weatherspoon, 2003; Briones, 2015; Reardon, Barrett, Berdegué, \& Swinnen, 2009; Schipmann \& Qaim, 2010). Promoting these institutions will help smallholders mitigate some of the transaction costs associated with market entry, as it addresses problems associated with economies of scale.

Cooperatives have been promoted globally to remedy the disadvantages of scale to small farms with differing levels of success (Devaux et al., 2009; Kherallah, Delgado, Gabre-Madhin, Minot, \& Johnson, 2002; Stockbridge, Dorward, \& Kydd, 2003). In countries like Japan, South Korea and Taiwan that were founded upon small farms, ${ }^{1}$ cooperatives were set up, and factors that put small farms at a disadvantage were neutralized through state-provisioned extension services, key inputs, irrigation and market intervention operations (Huang, 2006; Kajita, 1965; Lin, 2006). Aggregation of producers will help reduce the fixed cost of accessing resource and services and once made available these institutions can disseminate it with little additional costs.

${ }^{1}$ The average size of landholdings in Japan and Korea in the twenty-first century are 1.2 acres and 1 acre, respectively (Fan \& Chan-Kang, 2003) and less than 1 acre in Taiwan (Lam, 2006). 
However, in many developing countries and in India, cooperatives in the past have been less successful. Their effectiveness was limited by issues of poor organization and incompetent management, political interference in their functioning, financial irregularities and corruption within the organizations (Akwabi-Ameyaw, 1997; Attwood, 1982, 1987; Baviskar, 1987; Holloway, Nicholson, Delgado, Staal, \& Ehui, 2000; Lalvani, 2008). In India, the significant challenges the cooperatives faced were structural and incentive based. The structural problems were political and bureaucratic interference, poor management and governance, and elite capture of the activities to their benefit. Cooperatives also faced incentive problems characterized by dormant membership and poor participation of members, hindering the growth of these organizations. These incentive problems were due to non-percolation of benefits to members, especially the demography the cooperatives meant to empower.

Since the early 2000s, there has been a significant drive in India to promote producer organizations in the agricultural sector. The amendment of the Companies Act in 2003 that enabled the formation of Producer Companies (PCs) was a vital step in this direction. The producer-owner system increases the agency of members and reduces the role of the state and bureaucracy, preventing exogenous power capture. More agency for these organizations may prove to be a crucial step in addressing some of the structural issues that hindered the effectiveness of cooperatives. State support to set up aggregation models and capacity building to help producers manage these organizations and help in forming linkages to input and output markets will be important. These institutions can rectify scalerelated disadvantages for smallholders in accessing technology, credit, information and inputs while reducing transaction costs to enable commercialization.

\subsubsection{Land Tenure and the Question of Access to Land}

Unequal access to land has persisted in India due to the failure to implement land reforms post-independence. Although land reforms failed to redistribute land among cultivators, it did to an extent limit land tenure practices and made them in illegal in many states. The two central tenure practices are fixed rent contracts and sharecropping contracts (Chaudhuri \& Maitra, 1997). In a fixed rent contract, the tenant cultivates the land leased from the owner for a fixed share of the produce. The tenant bears the production risks and may not have the incentive to increase production over a certain level due to perceived risks. In a sharecropping contract, 
the tenant leases land from the owner and the rent is a percentage share of the total output. Here the owner and the tenant share the risk, and the tenant has a higher incentive to make investments on the farm.

According to the latest census data (2010-11), 86\% of agricultural land in India is less than two hectares in size. The number of small farms has increased by about $6 \%$ since 1991-92. Because of increasing fragmentation of land holdings, land leasing is an essential practice for improving access to land (Ballabh \& Walker, 1992; Bell, 1990; Melmed-Sanjak, 1998; Sadoulet, Murgai, \& de Janvry, 1998; Vaidyanathan, 1994). Although land tenancy has fallen considerably since the land reforms, according to the 2010-11 census of the Government of India, 10.4\% of rural households lease land. This figure ranges from 5\% in Madhya Pradesh to $36 \%$ in the erstwhile Andhra Pradesh. The Government of India in 2016 proposed a model land leasing act to enable the leasing of land. According to the Expert Committee report on land leasing (GOI, 2016), legalizing land leasing can encourage larger landowners and small and marginal farms alike. Larger landowners can lease out land through sharecropping when agricultural wages and monitoring costs are high without fear of losing ownership, while smallholders can lease out land and seek employment outside agriculture when non-farm wages increase, supplementing wages with land rent.

Legalizing land leasing can improve access to land. However, issues of how tenant farmers can access credit, as leased-in land is insufficient collateral, will need to be addressed. A study by Haque and Nair (2014) on the Kudumbashree Mission, a women's collective in Kerala, shows that women's collectives (of 2-10 members) jointly leasing in land to cultivate fruits and vegetables and tapioca earned on an average 42,000 rupees per acre. These women's groups also had access to collateral-free credit through Joint Liability Groups (JLGs), where the groups were jointly liable for the loans they took. Valuable lessons can be learned from such experiences.

\subsubsection{Agricultural Development in Eastern India-Rectifying Regional Disparities}

Improving agricultural production in regions that the Green Revolution did not benefit will be important to rectify regional disparity through agricultural development and improved incomes. Agriculture's share in state GDP of the eastern states of Bihar, Chhattisgarh, Jharkhand, Odisha, eastern Uttar Pradesh, West Bengal and Assam is high, while productivity 
remains low. Improving agricultural production in regions that did not reap the benefits of the Green Revolution is important to rectify regional disparity in agricultural development and incomes. According to the National Bureau of Soil Survey and Land Use Planning (NBSS\&LUP), the LGP in these regions is 240 days and the annual rainfall range from 1000 to $2500 \mathrm{~mm}$ per annum (GOI, 2015). The availability of groundwater in these regions is also high but remains untapped for agricultural development.

Despite these advantages, the exposure to abiotic stress resulting from droughts, floods and submergence is high due to poor access to irrigation and infrastructure of flood control. In many states such as Odisha, Assam, Jharkhand and Chhattisgarh, households only have a single sowing season. Eighty-two percent of the fallowed land is in the eastern part of India (Singh, Praharaj, \& Sandhu, 2016). In the post paddy season, the land is often left fallow although there is potential to grow crops such as pulses using the residual moisture of the previous season. Practices of open grazing and labor outmigration during this season also make the adoption of second sowing problematic. In these states mentioned above, the rate of migration to urban areas and urbanizing states are high as off-farm wages have increased in recent years resulting in the pull of labor from the agricultural sector.

Getting agricultural productivity going in these regions requires infrastructural development and institutional interventions. Development of irrigation in these regions is vital to reduce abiotic stress during the growing seasons. Micro-irrigation and communal irrigation facilities such as water user groups can help reduce overuse of water and promote judicious use of water resources. Improved access to irrigation and reduced abiotic stress resulting from late rainfall and drought, increase the scope for diversification and may improve access to credit as risks reduce. Improving access to cold chains and specific value chains for perishables will also improve connectivity to markets and marketing opportunities (this is discussed in detail in the next chapter). Institutional interventions such as good extension services, R\&D focused on the advantages of these regions and aggregation models to reduce the disadvantages of scale are especially relevant in the eastern states. This region may not have the same potential as Punjab, Haryana and the southern Delta regions in reaching yield potential in paddy, but have the scope to develop a comparative advantage in growing crops such as pulses and certain fruits and vegetables. 
Development of extension services to help with cropping transitions is essential. Traditionally, R\&D has focused on significant cereals, and extending this to other crops will disproportionately benefit these regions. Technologies in increasing yields in pulses and coarse grains, short duration crops to adjust to climatic conditions, and crops with improved resilience to abiotic stresses will be crucial to this region. These technologies along with mechanization can offset the effects of migration by reducing the drudgery of women and improving productivity. Lastly, aggregation models can remedy the disadvantages of scale in accessing resources and technology and will prove essential for the development of the agricultural sector in this region.

\subsection{CONCLUSION}

Growing population and changing demand have brought about opportunities for growth and challenges to the Indian agricultural sector. At the farm level, the ability of small farms to commercialize (increase engagement with input and output markets) and diversify will determine their scope to increase production and diversify in line with changing demand. However, the institutional challenges for small farms are their ability to access capital, technology and mechanization that are essential for commercialization. The Green Revolution was successful in India because the technologies that it brought were scale-neutral and small farms were able to take advantage of the higher productivity of family labor. Institutional support in the form of direct procurement of food grains, minimum support prices and input subsidies complemented technological measures to incentivize adoption. However, these GR technologies were concentrated on major food grains, were not resource-neutral and therefore were successful only in regions that had access to irrigation or had low agroclimatic risks.

Agricultural sector growth depends on rectifying interregional disparities and improving access to capital, mechanization and quality inputs such as yield increasing seed technologies to enable commercialization and diversification. As newer technologies are not scale-neutral and the advantages of family labor utilization are being eroded due to rising off-farm wages, access to capital and addressing the issues of economies of scale is critical. In this chapter, we looked at the scope of institutional interventions to rectify small farm disadvantages. We assessed the scope of aggregation models such as cooperatives and FPOs in 
rectifying the scale disadvantages of accessing capital and technology and suggested their widespread promotion in different parts of the country. We touched upon the need to revisit the issue of land reforms, not from the point of view of redistribution, but concerning reforming land tenure systems to improve access to land and better enable access to mechanization and credit. We also suggested that special attention be paid to agricultural development in eastern India that has a high potential for commercialization and diversification. Measures to improve access to yield increasing technologies and corresponding institutional support in the form of increased access to credit, R\&D and information will be essential. Interventions on these lines can help align supply conditions to changing demand to utilize the opportunities for growth for smallholder agriculture.

\section{REFERENCES}

Abraham, M., \& Pingali, P. (2019). Shortage of pulses in India: Understanding how markets incentivize supply response. Journal of Agribusiness in Developing and Emerging Economies, forthcoming.

Agarwal, B. (2010). Rethinking agricultural production collectivities. Economic and Political Weekly, 45(9), 64-78.

Akwabi-Ameyaw, K. (1997). Producer cooperative resettlement projects in Zimbabwe: Lessons from a failed agricultural strategy. World Development, $25,437-456$.

Attwood, D. W. (1982). Class interests and changes in the organisation of production in the Indian sugar industry. Paper presented at the annual meeting of the Social Science History Association (Vol. Bloomington).

Attwood, D. W. (1987). Social and political preconditions for successful cooperatives: The cooperative sugar factories of western India. In D. W. Attwood \& B. S. Baviskar (Eds.), Cooperatives and rural development. New Delhi and Oxford: Oxford University Press.

Ballabh, V., \& Walker, T. S. (1992). Land fragmentation and consolidation in dry semi-arid tropics of India. Artha Vijnana, 34(4), 363-387.

Bardhan, P. (1973). Size, productivity and returns to scale: An analysis of farmlevel data in Indian agriculture. Journal of Political Economy, 81(6), 1370-1386.

Bardhan, P. (1996). The nature of institutional impediments to economic development. Mimeo. Retrieved from https://ageconsearch.umn.edu/ record/233429/files/cal-cider-c096-066.pdf

Barrett, C. B., Bachke, M. E., Bellemare, M. F., Michelson, H. C., Narayanan, S., \& Walker, T. F. (2012). Smallholder participation in contract farming: Comparative evidence from five countries. World Development, 40(4), 715-730. https://doi.org/10.1016/j.worlddev.2011.09.006 
Baviskar, B. S. (1987). Cooperatives and rural development in India. Current Anthropology, 28(4), 564-565.

Bell, C. (1990). Reforming property rights in land and tenancy. World Bank Research Observer, 5(2), 143-166.

Bellemare, M. F. (2012). As you sow, so shall you reap: The welfare impacts of contract farming. World Development, 40(7), 1418-1434. https://doi. org/10.1016/j.worlddev.2011.12.008

Benjamin, D. (1995). Can unobserved land quality explain the inverse productivity relationship? Journal of Development Economics, 46, 51-84.

Bernstein, H. (2010). Class dynamics of agrarian change. West Hartford, CT: Kumarian Press.

Besley, T. (1995a). Property rights and investment incentives: Theory and evidence from Ghana. Journal of Political Economy, 103(5), 903-937.

Besley, T. (1995b). Savings, credit and insurance. In J. Behrman \& T. N. Srinivasan (Eds.), The handbook of developmental economics (pp. 2124-2207). Amsterdam: Elsevier Science Publishers, B.V.

Bhaduri, A. (1977). On the formation of usurious interest rates in backward agriculture. Cambridge Journal of Economics, 1(4), 341-352.

Bhalla, G. S., \& Singh, G. (2010). Growth of Indian agriculture: A district level study. Final report submitted to Planning Commission, Government of India, New Delhi.

Bhalla, S. S., \& Roy, P. (1988). Mis-specification in farm productivity analysis: The role of land quality. Oxford Economic Papers, 40(1), 55-73.

Binswanger-Mkhize, H. P. (2013). The stunted structural transformation of the Indian economy: Agriculture, manufacturing and the rural non-farm sector. Economic and Political Weekly, 48, 5-13. Retrieved from https://www.epw.in/ journal/2013/26-27/review-rural-affairs-review-issues/stuntedstructuraltransformation-indian

Binswanger, H. P., \& Khandker, S. (1992). The impact of formal finance on the rural economy of India (No. 949). Washington, DC.

Binswanger, H. P., \& Rosenzweig, M. R. (1986). Behavioural and material determinants of production relations in agriculture. Journal of Development Studies, 22, 503-539.

Binswanger, H. P., \& Singh, S. K. (2017). Wages, prices and agriculture: How can Indian agriculture cope with rising wages? Journal of Agricultural Economics, 69(2), 281-305. https://doi.org/10.1111/1477-9552.12234

Birner, R., \& Resnick, D. (2010). The political economy of policies for smallholder agriculture. World Development, 38(10), 1442-1452. https://doi. org/10.1016/j.worlddev.2010.06.001

Boselie, D., Henson, S., \& Weatherspoon, D. (2003). Supermarket procurement practices in developing countries: Redefining the roles of the public and private sectors. American Journal of Agricultural Economics, 85(5), 1155-1161. 
Briones, R. M. (2015). Small farmers in high-value chains: Binding or relaxing constraints to inclusive growth? World Development, 72, 43-52. https://doi. org/10.1016/j.worlddev.2015.01.005

Carletto, C., Corral, P., \& Guelfi, A. (2017). Agricultural commercialization and nutrition revisited: Empirical evidence from three African countries. Food Policy, 67, 106-118. https://doi.org/10.1016/j.foodpol.2016.09.020

Chaudhuri, A., \& Maitra, P. (1997). Determinants of land tenure contracts; Theory and evidence from rural India. Department of Economics-Departmental Working Papers.

de Janvry, A., \& Subbarao, K. (1986). Agricultural price policy and income distribution in India. New Delhi: Oxford University Press.

Devaux, A., Horton, D., Velasco, C., Thiele, G., López, G., Bernet, T., ... Ordinola, M. (2009). Collective action for market chain innovation in the Andes. Collective Action for Smallholder Market Access, 34(1), 31-38. https:// doi.org/10.1016/j.foodpol.2008.10.007

Dorward, A., Kydd, J., Morrison, J., \& Urey, I. (2004). A policy agenda for propoor agricultural growth. World Development, 32(1), 73-89.

Eastwood, R., Lipton, M., \& Newell, A. (2010). Farm size. Handbook of Agricultural Economics, 4, 3323-3397. https://doi.org/10.1016/ S1574-0072(09)04065-1

Eswaran, M., \& Kotwal, A. (1986). Access to capital and agrarian production organisation. Economic Journal, 96(382), 482-498.

Fan, S., \& Chan-Kang, C. (2003). Is small beautiful? Farm size, productivity and poverty in Asian agriculture. In Proceedings of the 25th International Conference of Agricultural Economists, Durban, South Africa.

Feder, G. (1985). The relation between farm size and farm productivity. Journal of Development Economics, 18, 297-313.

Feder, G., Just, R. E., \& Zilberman, D. (1985). Adoption of agricultural innovations in developing countries: A survey. Economic Development and Cultural Change, 33(2), 255-298. https://doi.org/10.1086/451461

Ferroni, M., \& Zhou, Y. (2017). The private sector and India's agricultural transformation. Global Journal of Emerging Market Economies, 9(1-3), 28-37. https://doi.org/10.1177/0974910117716406

Freebairn, D. K. (1995). Did the green revolution concentrate incomes? A quantitative study of research reports. World Development, 23(2), 265-279. https:// doi.org/10.1016/0305-750X(94)00116-G

Ghosh, J. (2013). Microfinance and the challenge of financial inclusion for development. Cambridge Journal of Economics, 37(6), 1203-1219.

Ghosh, P., Mookherjee, D., \& Ray, D. (2001). Credit rationing in developing countries: An overview of the theory. In D. Mookherjee \& D. Ray (Eds.), Readings in the theory of economic development (pp. 283-301). Malden, MA: Blackwell Publishing Ltd.

GOI. (2015). Raising agricultural productivity and making farming remunerative for farmers. New Delhi. 
GOI. (2016). Report of the expert committee on land leasing. New Delhi.

Goldman, A., \& Smith, J. (1995). Agricultural transformations in India and Northern Nigeria: Exploring the nature of Green Revolutions. World Development, 23(2), 243-263. https://doi.org/10.1016/0305-750X(94)00115-F

Gulati, A., Jain, S., \& Satija, N. (2014). Rising farm wages in India-The 'pull' and 'push' factors. Journal of Land and Rural Studies, 2(2), 261-286. https:// doi.org/10.1177/2321024914534045

Haque, T., \& Nair, J. L. (2014). Ensuring and protecting the land leasing right of poor women in India. Paper prepared for presentation at the "2014 World Bank Conference on Land and Poverty", The World Bank.

Hazell, P. (2018). Urbanization, agriculture and smallholder farming. In R. Serraj \& P. Pingali (Eds.), Agriculture and food systems to 2050: Global trend, challenges and opportunities (pp. 137-160). Singapore: World Scientific.

Hazell, P., Poulton, C., Wiggins, S., \& Dorward, A. (2010). The future of small farms: Trajectories and policy priorities. World Development, 38(10), 1349-1361. https://doi.org/10.1016/j.worlddev.2009.06.012

Holloway, G., Nicholson, N., Delgado, C., Staal, S., \& Ehui, S. (2000). Agroindustrialization through institutional innovation: Transaction costs, cooperatives and milk-market development in the east-African highlands. Agricultural Economics, 23, 279-288.

Huang, J. (2006). Taiwan in transformation, 1895-2005: The challenge of a new democracy to an old civilization. New Brunswick, NJ: Transaction Publishers.

Johnson, N. L., \& Ruttan, V. W. (1994). Why are farms so small? World Development, 22(5), 691-706. https://doi.org/10.1016/0305-750X(94)90044-2

Kajita, M. (1965). Land policy after land reforms in Japan. Developing Economies, 3(1), 88-105. https://doi.org/10.1111/j.1746-1049.1965.tb00749.x

Kherallah, M., Delgado, C., Gabre-Madhin, E., Minot, N., \& Johnson, M. (2002). Reforming agricultural markets in Africa. Baltimore, MD: John Hopkins University.

Kumar, A., Yadav, C., Jee, S., Kumar, S., \& Chauhan, S. (2011). Financial innovation in Indian agricultural credit market: Progress and performance of Kisan Credit Card. Indian Journal of Agricultural Economics, 66(3), 418-428.

Lalvani, M. (2008). Sugar co-operatives in Maharashtra: A political economy perspective. Journal of Development Studies, 44(10), 1474-1505. https://doi. org/10.1080/00220380802265108

Lam, W. F. (2006). Foundations of a robust social-ecological system: Irrigation institutions in Taiwan. Journal of Institutional Economics, 2(2), 203-226.

Lin, D. (2006). Agricultural cooperatives in Taiwan. In 2006 FFTC-NACF International Seminar on Agricultural Cooperatives in Asia: Innovations and Opportunities in the 21st Century. Seoul, Korea.

Mani, G. (2016). Study on implementation of Kisan Credit Card scheme. Occasional Paper No. 64.

Mazumdar, D. (1965). Size of farm and productivity-A problem of Indian peasant agriculture. Economica, 32(126), 161-173. 
Melmed-Sanjak, J. (1998). A review of the literature on land leasing arrangements in selected Asian countries. Rome.

Mosley, P. (2002). The African green revolution as a pro-poor policy instrument. Journal of International Development, 14(6), 695-724. https://doi. org/10.1002/jid.912

National Sample Survey Organisation (NSSO). (2014). Key indicators of situation of agricultural households in India. National Sample Survey 70th Round, Ministry of Statistics and Programme Implementation, Government of India, New Delhi.

Pattnaik, I., Lahiri-Dutt, K., Lockie, S., \& Pritchard, B. (2018). The feminization of agriculture or the feminization of agrarian distress? Tracking the trajectory of women in agriculture in India. Journal of the Asia Pacific Economy, 23(1), 138-155. https://doi.org/10.1080/13547860.2017.1394569

Pingali, P. (2012). Green revolution: Impacts, limits, and the path ahead. Proceedings of the National Academy of Science, 109(31), 12302-12308. https://doi.org/10.1073/pnas.0912953109

Pingali, P. (2015). Agricultural policy and nutrition outcomes-Getting beyond the preoccupation with staple grains. Food Security, 7(3), 583-591. https:// doi.org/10.1007/s12571-015-0461-x

Pingali, P., Khwaja, Y., \& Madelon, M. (2005). Commercializing small farms: Reducing transaction cost. ESA Working Paper (No.), 05-08.

Pingali, P., \& Rosegrant, M. W. (1995). Agricultural commercialization and diversification: Processes and policies. Food Policy, 20(3), 171-185. https://doi. org/10.1016/0306-9192(95)00012-4

Poulton, C., Dorward, A., \& Kydd, J. (2010). The future of small farms: New directions for services, institutions, and intermediation. World Development, 38(10), 1413-1428. https://doi.org/10.1016/j.worlddev.2009.06.009

Prakash, P., \& Kumar, P. (2016). Performance of Kisan Credit Card scheme in Tamil Nadu. Indian Journal of Agricultural Economics, 71(2), 191-211.

Pray, C. E., \& Nagarajan, L. (2014). The transformation of the Indian agricultural input industry: Has it increased agricultural R\&D? Agricultural Economics, 45(S1), 145-156. https://doi.org/10.1111/agec.12138

Reardon, T., Barrett, C. B., Berdegué, J. A., \& Swinnen, J. F. M. (2009). Agrifood industry transformation and small farmers in developing countries. World Development, 37(11), 1717-1727. https://doi.org/10.1016/j.worlddev. 2008.08.023

Reardon, T., \& Timmer, P. C. (2007). Chapter 55 Transformation of markets for agricultural output in developing countries since 1950: How has thinking changed? In Handbook of agricultural economics (Vol. 3, pp. 2807-2855). Elsevier. https://doi.org/10.1016/S1574-0072(06)03055-6

Sadoulet, E., Murgai, R., \& de Janvry, A. (1998). Access to land via land rental markets. 
Schaffner, D. J., Schroder, W. R., \& Earle, M. D. (1998). Food marketing: An international perspective. Boston, MA: WCB McGraw-Hill.

Schipmann, C., \& Qaim, M. (2010). Spillovers from modern supply chains to traditional markets: Product innovation and adoption by smallholders. Agricultural Economics, 4l(3-4), 361-371. https://doi.org/10.1111/ j.1574-0862.2010.00438.x

Sen, A. K. (1962). An aspect of Indian agriculture. The Economic Weekly, 14(46), 243-246.

Sen, A. K. (1966). Peasants and dualism with or without surplus labor. Journal of Political Economy, 74, 425-450.

Singh, N., Praharaj, C., \& Sandhu, J. (2016). Utilizing untapped potential of rice fallow of East and North-east India through pulse production. Indian Journal of Genetics and Plant Breeding, 76(4), 388-398.

Stockbridge, M., Dorward, A., \& Kydd, J. (2003). Farmer organizations for market access: Learning from success. Volume Briefing Paper. London, UK: Wye College, University of London.

Vaidyanathan, A. (1994). Agrarian relations in the context of new agricultural technology: An issues paper. Indian Journal of Agricultural Economics, $49(3), 317-329$.

Varshney, A. (1998). Democracy, development, and the countryside: Urban-rural struggles in India. https://doi.org/10.1017/CBO9780511609367

von Braun, J. (1995). Agricultural commercialization: Impacts on income and nutrition and implications for policy. Food Policy, 20(3), 187-202. https://doi. org/10.1016/0306-9192(95)00013-5

Open Access This chapter is licensed under the terms of the Creative Commons Attribution 4.0 International License (http://creativecommons.org/licenses/ by $/ 4.0 /$ ), which permits use, sharing, adaptation, distribution and reproduction in any medium or format, as long as you give appropriate credit to the original author(s) and the source, provide a link to the Creative Commons licence and indicate if changes were made.

The images or other third party material in this chapter are included in the chapter's Creative Commons licence, unless indicated otherwise in a credit line to the material. If material is not included in the chapter's Creative Commons licence and your intended use is not permitted by statutory regulation or exceeds the permitted use, you will need to obtain permission directly from the copyright holder.

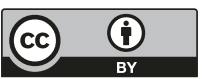

